\title{
Charles Darwin's Traverse of the South Pacific: A New Appraisal
}

\author{
Patrick Armstrong \\ Department of Geography and Planning, University of Western Australia, Nedlands, Australia
}

Received October 31, 2021; Revised December 11, 2021; Accepted January 16, 2022

\section{Cite This Paper in the following Citation Styles}

(a): [1] Patrick Armstrong, "Charles Darwin's Traverse of the South Pacific: A New Appraisal," Environment and Ecology Research, Vol. 10, No. 1, pp. 69 - 86, 2022. DOI: 10.13189/eer.2022.100107.

(b): Patrick Armstrong (2022). Charles Darwin's Traverse of the South Pacific: A New Appraisal. Environment and Ecology Research, 10(1), 69 - 86. DOI: 10.13189/eer.2022.100107.

Copyright $\bigcirc 2022$ by authors, all rights reserved. Authors agree that this article remains permanently open access under the terms of the Creative Commons Attribution License 4.0 International License

\begin{abstract}
H.M.S. Beagle in 1835-36 spent 127 days on the transect of the South Pacific Ocean with Charles Darwin aboard. 54 of those days were spent in or near island environments as the ship visited several of the Islands of the Galápagos, the main island of Tahiti and the Bay of Islands, New Zealand: Darwin also had good views of about a dozen other islands. His methods of working were largely similar to that adopted on other sectors of the voyage - the transects of the Atlantic and Indian Oceans. He was relatively well-equipped, observed and recorded carefully, constantly revising his notes as new information came to hand and as he compared one island environment with another. Although there are few signs of evolutionary insights at this stage, he was using conceptual frameworks that were important to him later. Thus, he was interested in the behaviour of animals, sometimes adopted an ecological approach, and was considering landscapes in the context of change through geological time. There are signs that he was already adopting a 'Lyellian' or gradualist viewpoint, particularly in the context of the development of volcanic and coral islands. This paper evaluates these visits, where appropriate, making comparisons with recent visits by the present author, in which he has attempted 'to take the archives to the field' comparing the present situation with Darwin's records.
\end{abstract}

Keywords Charles Darwin, Geology, Gradualism, Islands, Pacific Ocean, Sea Level Change

\section{Introduction}

Charles Darwin's 'Voyage of the Beagle' can be seen in terms of four major oceanic transects: Atlantic Southbound (Plymouth, England to Tierra del Fuego, December 1831 May 1834), the Pacific (Callao, Peru to Port Jackson [Sydney], Australia, September 1835 to January 1836), the Indian Ocean (King George's Sound, Australia to Cape Town, South Africa, March 1836 - May 1836); the Atlantic Ocean, Northbound (Cape Town to Falmouth, June to October, 1836). These oceanic traverses were broken and interspersed, by shorter marine links (eg Sydney via, Hobart Town, across the Great Australian Bight to King George's Sound in Western Australia) and continental excursions (eg, those in South America, Australia, and the Cape of Good Hope, some of which lasted several weeks). A case can be made for analysing the voyage in terms of each of these oceanic traverses (eg Armstrong, 2015 [1], for the Indian Ocean, with which this current analysis may be compared).

H.M.S. Beagle, left Callao in Peru on 7 September 1835, and, he wrote: 'Early in the morning' of 12 January 1836 'a light air carried us towards the entrance of Port Jackson [Sydney, New South Wales, Australia]'. He had spent many months previously exploring Tierra del Fuego, the Islands of Chiloé and of the Chronos Archipelago, and the Andes; in the weeks ahead he was to cross the Blue Mountains of New South Wales, and spend a fortnight in Tasmania. These land areas are within the 'Pacific Basin' although the actual South Pacific traverse, continent to continent, only occupied 127 days. Yet Macleod and Rehbock (1994) [2] felt able to write:

The Pacific played a central role in shaping Darwin's experience of nature and the nature of modern science... As the Pacific shaped Darwin, so Darwin shaped the Pacific (p.ix). 


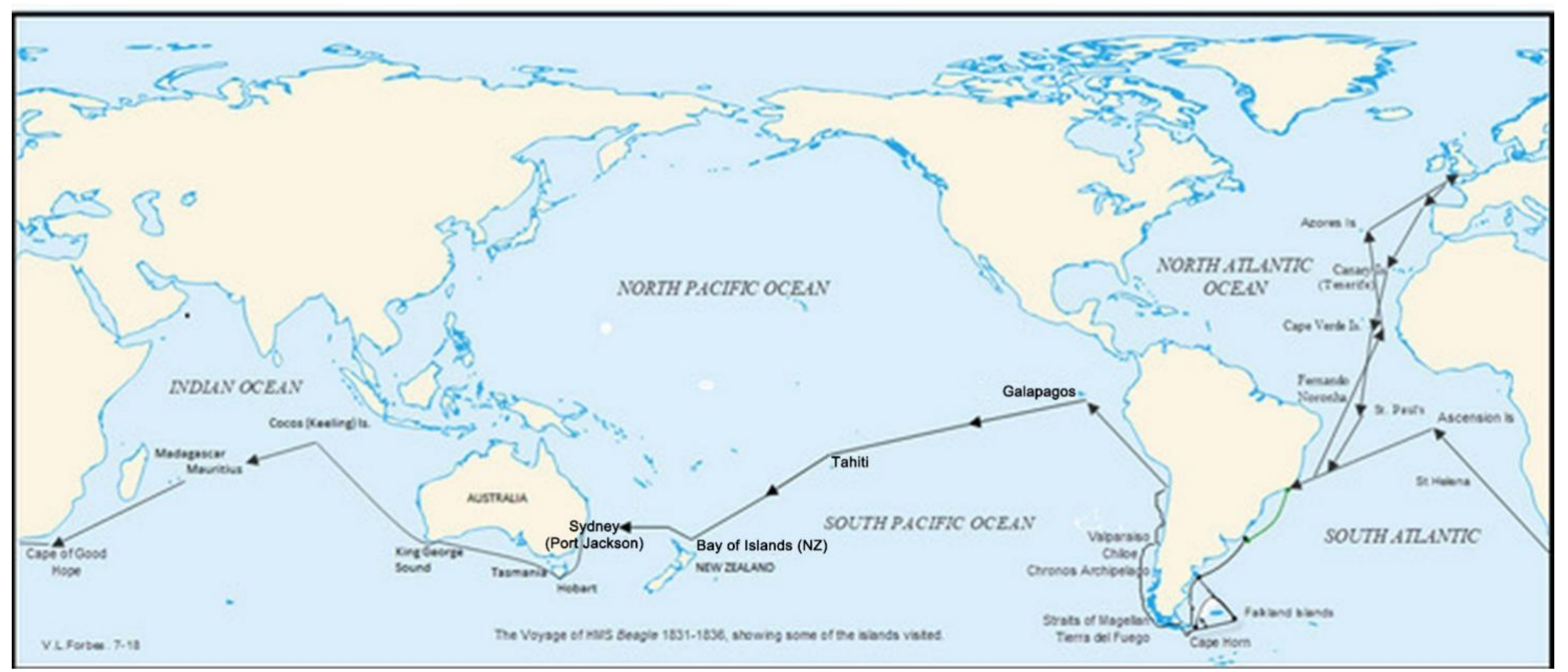

Figure 1a. The traverse of the Pacific Ocean as part of the voyage of the Beagle, 1831-1836 


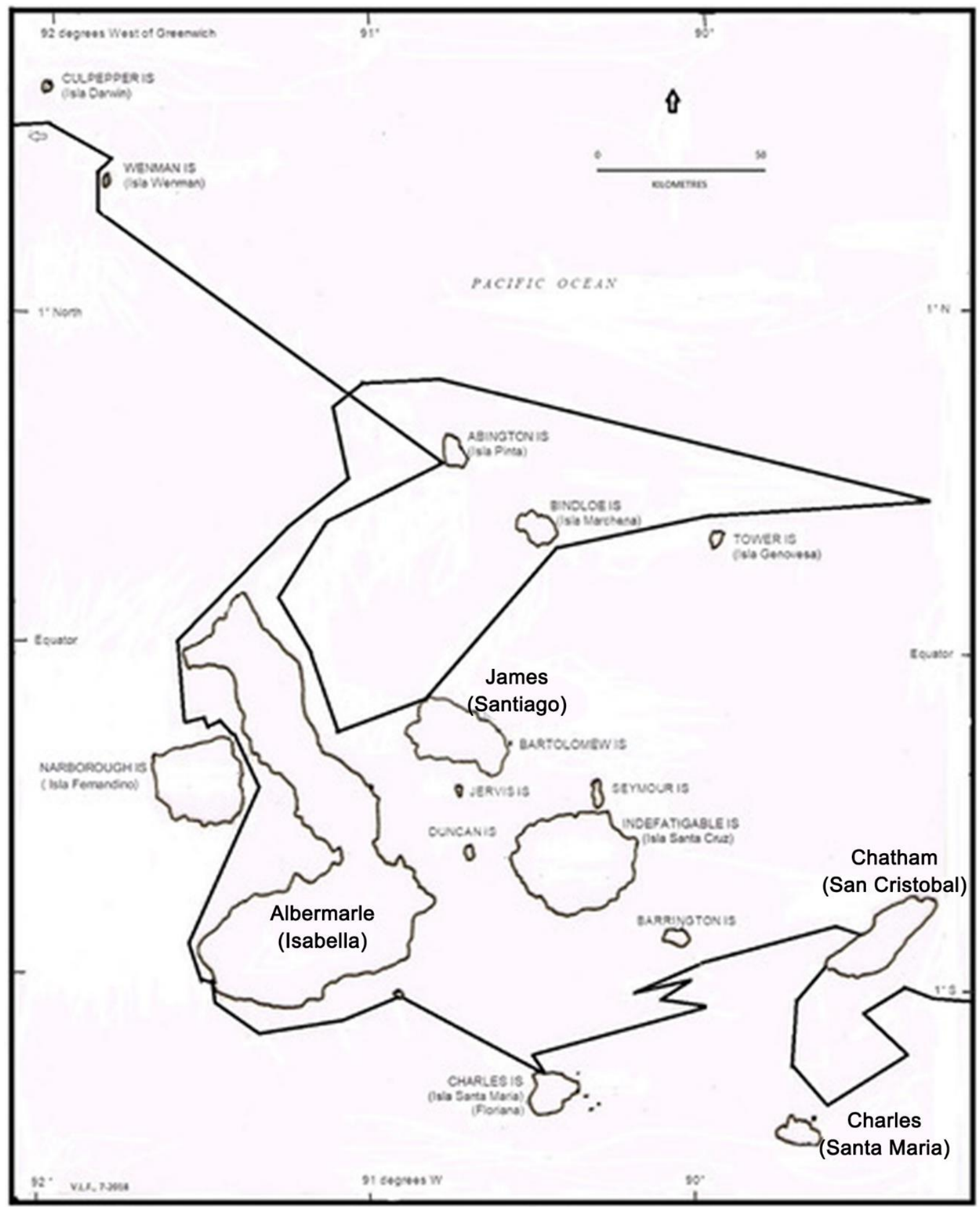

Figure 1b. The approximate course of HMS Beagle through the Galápagos Islands, 1835. Charles Darwin was not aboard throughout the whole of this period, but was sometimes exploring individual islands

The visits to the islands of the South Pacific (and the voyages between them) were significant in the development of Charles Darwin's ideas, but they should not be overemphasised to the exclusion of other parts of the voyage. They should be viewed in the context of the Beagle experience as a whole, and in particular in relation to his sojourns upon other islands and island groups that Darwin visited in the Atlantic and Indian Oceans, on a voyage that lasted nearly five years. The methods used, and conceptual frameworks employed were generally similar throughout the entire voyage.

After leaving Callao, H.M.S. Beagle visited the 
Galápagos, 15 September - 19 October, Tahiti, 17 - 26 November, and the Bay of Islands, on the North Island of New Zealand 19 - 30 December 1835. (It is of note that the Beagle anchored, while in Tahiti, at Point Venus, close to where Captain Cook's Endeavour anchored in 1769: Figure 2.) Of the total 127 days, Darwin was only about 54 days on or near islands, but that total includes substantial periods in harbour, or aboard ship adjacent to the shore, working on specimens or writing up his diary or notes.

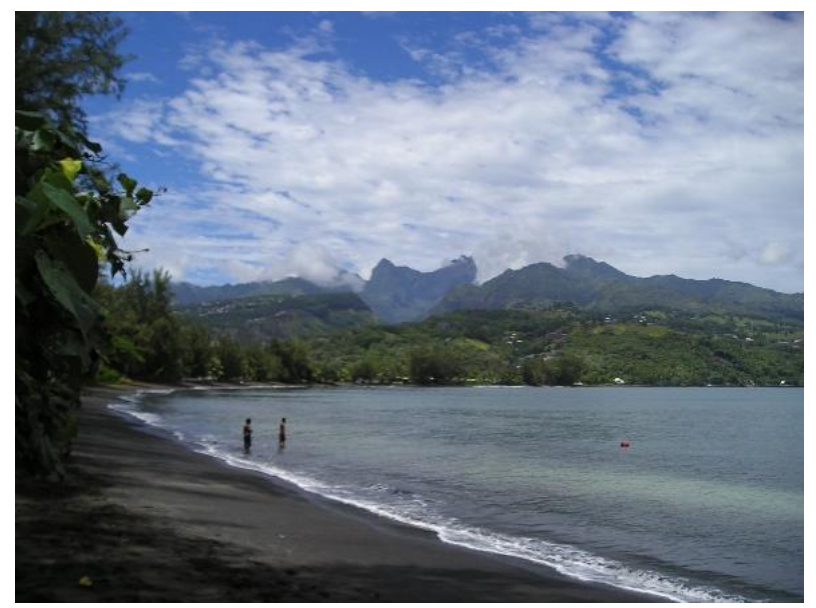

Figure 2. Port Venus, Tahiti; anchorage of HMS Beagle in 1835, and also of Captain Cook's H.M.S. Endeavour in 1769

\section{Aims and Methods}

The aim has been to 'take the archives into the field' and, as far as possible, to visit the exact locations that Darwin visited during his voyage with photocopies of his Beagle notes, and his other writings, in hand. In this way, an attempt was to locate the precise sites he visited, and from whence he collected specimens, the routes he took, and indeed to understand more precisely how he worked and how he reacted to particular environments. The Bay of Islands in New Zealand was visited in September 1988, Tahiti in October 2002, and the Galápagos in May 2016. Some photographs were taken at these times. The chronology of the transect has been previously discussed (Armstrong, 1992 [3,4], 2004 [5]; Estes, Grant and Grant, 2000 [6]; Grant and Estes, 2009 [7]), as have Darwin's rather negative feelings towards both the Galápagos and New Zealand. Here the focus is more on his techniques of collecting and observing, and the development of his ideas.

The transcription of the Diary used was that of Barlow (1933) [8] - there are others but this is widely available. Darwin's Geological Diary and Zoological Diary are held in the Manuscript Collection of Cambridge University Library, whereat they were inspected. However, these documents, together with a major part of the Darwin Archive (generally indicated here by the prefix DAR) are mostly now available online at: http://darwin-online.org.uk/manuscripts.html His 'little note-books' (abbreviated $N B$ ) containing his rough jottings, many of which were made in the field, are published by Chancellor and van Wyhe (2009) [9]. (Here we are mainly concerned with the Galápagos notebook, see below.) Darwin's own publications from the voyage The Zoology of the Voyage of the Beagle and The Geology of the Voyage of the Beagle have been republished several times, and are also available at Darwin Online. Information on Darwin's Insects was published by the British Museum (Natural History) by K. G. V. Smith in 1987 [10].

\section{Darwin's Methodology}

\subsection{Darwin's Working Methods - On Land}

In general Darwin's methodology during the Pacific traverse was similar to that at other locations visited during the voyage. Sometimes Darwin used the Beagle as a base, making day excursions onto islands that interested him. Occasionally (as in Tahiti and at the Bay of Islands, New Zealand), he employed a local guide. Sometimes he was accompanied by other members of the Beagle's crew: on James Island (Santiago) in the Galápagos he was accompanied by Lt Bartholomew Sullivan, as well as, on one occasion 'Mr [Benjamin] Bynoe [the ship's surgeon] $\&$ three men.' Short excursions would have reduced the amount of gear he (and his servant, Syms Covington) had to carry. In any case some equipment, such as the blowpipe for testing mineralogical specimens, was left on board. On occasion, he spent the night ashore, using tents when setting up a temporary base while away from the Beagle. In Tahiti he bivouacked, or slept in the open. Obstructions and difficulties did not deter him: in Tahiti, when ascending a steep slope in a mountain valley, he used ropes (Galápagos $N B$ page 53b), and when investigating a coral reef in Tahiti, he borrowed a canoe (Diary, 22 November 1835).

He had at least one insect net: many specimens are described as being caught in this way (eg 'small insects, sweeping high up central parts of Charles Island [Galápagos]'), and a pair of 'forceps' or 'fly nippers'. He had several guns for shooting birds, and carried a telescope and a hand lens. Birds and reptiles were inspected for parasites - thus mites from the marine iguanas and tortoises on the Galápagos were collected (Smith, 1987)[10]. Plants were collected in a vasculum, although plant collecting was sporadic - the collection from the Galápagos was amongst the most thorough. Animal carcasses and stones were overturned in the search for beetles, and dead wood was carefully inspected ['Scolytus. Branches of dead Mimosa tree (long cavities, in whole length of branches)'; 'Insects inhabiting rotten wood. N Zealand']. Specimens were placed in 'bottles' or 'pill-boxes' (Smith, 1987) [10].

In his younger days, Darwin had been a quite keen angler, and he records having fish hooks with him on the voyage. A number of fish specimens (preserved in spirits) 
were collected at each of the Galápagos, Tahiti and New Zealand (these included some freshwater species). He also ate 'eels \& cray-fish' from a 'little stream' high in the hills of Tahiti! However, the seamen on the Beagle often fished for food at ports of call, offering to sell the odd interesting specimen to the young naturalist. His Diary entry for 17 September 1835 at Charles Island (Santa Maria, Floreana) describes such a scene:

The Bay swarmed with animals: Fish, Shark \& Turtles were popping up their heads in all parts. Fishing lines were soon put overboard \& great numbers of fine fish $2 \&$ even 3 feet [approx. $60-90 \mathrm{~cm}]$ long were caught. This sport makes all hands very merry; loud laughter and heavy flapping of fish are heard on every side.

He thus collected many hundreds of insects, shells, fish, plants, rocks, and reptiles during the transect across the Pacific. Frequently in the Diary are remarks such as 'We all were busily employed in collecting all sorts of specimens.' (12-16 October, 1835)

But above all he observed - he paid attention to plants, animals, rocks, landforms, and human communities. He was intensely interested in everything around him.

He had a thermometer; thus he noted the temperature at $85^{\circ} \mathrm{F}\left[29.4^{\circ} \mathrm{C}\right]$ 'in the tents', $95^{\circ} \mathrm{F}\left[35^{\circ} \mathrm{C}\right]$ in the open and $137^{\circ} \mathrm{F}\left[58.3^{\circ} \mathrm{C}\right]$ on the sand while on James Island [Santiago], in the Galápagos. He was often quite careful about recording the weather. He used a hammer to break fragments of rock: he (and those who accompanied him) must sometimes have born a substantial load of rock specimens back to the ship. He also possessed a clinometer (for measuring angles) and a 'Kater Azimuth Compass', at the time a type of instrument widely used by explorers and the British Army. He may have had with him a 'Mountain Barometer' on all his island visits. He possessed one but sometimes noted that he regretted not having it with him; but he does record a height of 2000ft $(610 \mathrm{~m})$ on Charles Island on 26 or 27 September 1835 (Diary), and a mound on Albermarle (now Isabela) as being 4000ft (1220m) (NB) $\mathrm{He}$ tried to give accurate measurements of the size of organisms, rock formations and landforms whenever he could.

Darwin also was closely observant of larger scale phenomena, describing landforms carefully, making shrewd deductions about their origin, and occasionally attempting to sketch them. Here he is describing the manner in which the low volcanic cones stand out from the generally rather flat, but undulating, expanses of the lava flows on the Galápagos:

From one point of view I counted 60 of these truncated hillocks, which are only 50 to $100 \mathrm{ft}$ [approx. 15.2-30.5 m] above the plain of lava. ... Such a surface has been aptly compared to a sea petrified in its most boisterous moments (Diary, 21 September 1835).

The description of the lava as resembling the "petrified waves' of a turbulent sea resonates with the modern visitor (figure.3).

In the field, Darwin usually wrote his rough notes in small leather-covered note-books, labelled 'Velvet paper memorandum book'. The notes for the Galápagos and Tahiti are in just such a 'little note-book' $(N B)$, which had around 100 pages. The note-books used by Darwin were about $120 \mathrm{~mm} \times 100 \mathrm{~mm}$, but, alas, this note-book (English Heritage classification number 88202337) has disappeared from Down House (Darwin's home after he was married) so a precise description cannot be given. Fortunately, it was microfilmed in 1969, and the contents were reproduced in Chancellor and van Wyhe (2009) [9].

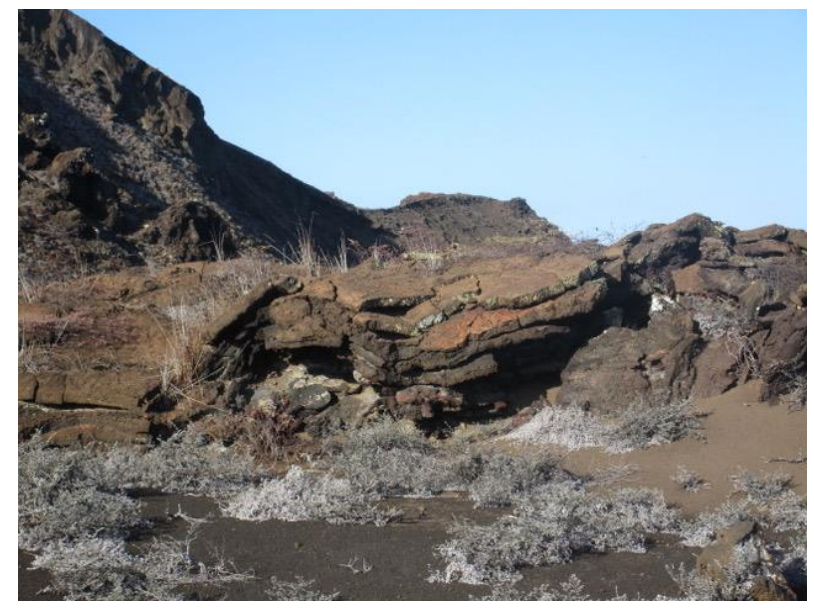

Figure 3. Dark coloured lava 'like sea petrified in its most boisterous most moments', with desert-like plants. Galápagos Islands

\subsection{Darwin's Method of Working - At Sea}

On 20 October 1835, after quick surveys of two small outlying islands of the Galápagos archipelago, Darwin records: 'the Ship's head was put toward Otaheitie \& we commenced our long passage of 3,200 miles [5,150km].' Around 73 days of the total transect were spent at sea, and this sector represented the largest portion. Some natural history observations almost certainly continued. Early in the voyage, while still in the Atlantic tropics he wrote:

I proved today the utility of a contrivance which will afford me many hours of amusement \& work, it is a bag four feet deep, made of bunting, \& attached to [a] semicircular bow: this by lines is kept upright, \& dragged behind the vessel. This evening it brought up a mass of small animals and tomorrow I look forward to a greater harvest (Diary, 10 January 1832).

There is every reason to suppose that he utilised this device (or something similar) in the Pacific. But there were other occasional moments of interest to the naturalist.

Darwin notes that 'early in the night of 3 Nov [1835], Many 100 miles from land in [the] Pacifick [sic]' a seabird was shot. This specimen is recorded in his note and in the Birds volume of the Zoology of the Voyage [11] (vol. 3, page 145) as Megalopterus stolidus, modern scientific 
name: Anous stolidus, $L$, the Brown Noddy. Darwin was constantly on the look-out for specimens. A few days later, the approach to an island was advertised by the 'great and increased numbers of sea-birds, especially two species of Terns' (Diary, 9 November 1835), which also attracted Darwin's interest.

Similarly, on the crossing from Tahiti to New Zealand, on 11 December (at exactly $180^{\circ} \mathrm{E}$ and $\mathrm{W}$ and $28^{\circ} \mathrm{S}$ ) a small group of white terns (possibly Gygis alba, Sparrman) was seen.

As explained below, the form and structure of some of the small Pacific islands was of great interest to Darwin, and he seems several times to have climbed to the masthead to gain a better view of the atolls that the ship passed (Diary, 18 November 1835).

\subsection{At Sea - Reworking the Data: The Flow of Ideas}

Although Darwin was occasionally sea-sick, the long sectors of the trans-Pacific voyage were probably fairly restful interludes, in contrast to the phrenetic travelling on foot, and collecting and observing while on islands. In later life, he corresponded with Philip Gidley King (who at the time of the voyage was a midshipman), recalling their times chatting on deck during the tropical nights. But there was nevertheless work to be done. The hundreds of specimens collected during the island visits were preserved, sorted, stored, labelled, listed, and described. There were, for example, different lists for rocks, shells and insects. Some of the clerical work was done by his servant, Syms Covington. During the long crossings, the brief, abbreviated notes in the 'little note-book' $(N B)$ were expanded: the Diary might thus be written up many days after the event. For example, on 18 November, on a hike into the interior of Tahiti, Darwin had written in his note-book ( $N B$ page $59 \mathrm{~b}$ ):

After supper baked in stones fine vegetables. Walked up to a little way Banana grove by Valley. Heard another cataract of $200 \mathrm{ft}$ - peaks in front $<45^{\circ}-$ Evening sublime -

The notes provided were just enough to jog his recollection. In the Diary, the account of the incident is expanded from memory; thus, some days later on the voyage to New Zealand, the style improved, and further editing effected:

These green parcels [vegetables wrapped in banana leaves] were laid in a layer between two of the hot stones \& the whole covered in earth, so that no smoke or steam escaped. In about a quarter of an hour the whole was most deliciously cooked ...

As the evening drew to a close, I strolled alongside of the stream, beneath the gloomy shade of the Bananas. My walk was soon brought to a close by coming to a Waterfall of two or three hundred feet high....

[T] he highest pinnacles of the central mountains towering up within sixty degrees of the Zenith, half hid the evening sky...

The Diary in turn provided the basis of the published Journal of Researches, in later editions known as The Voyage of the Beagle.

Similarly, the fragmentary geological notes from the note-books were worked up. While on this same excursion in Tahiti (figures 4 and 5), he wrote ( $N B$, pages 57b, 58b):

Geology - rocks chiefly grey base, with nests of olivine vesicular in bands, some hard conglomerates - fragments of Trachyte \& /do/ large Crysts of glassy Feldspar and Hornblende volcanic clay and Sandstones, Great pile of Lavas eat through by rivers.-

In his Geological Diary, also probably written up on the voyage between Tahiti and the Bay of Islands, New Zealand, these brief jottings are expanded to:

In the central mountains the commonest rock is a blackish grey olivine. Lava nests of olivine,- its structure is frequently columnar 3376. - There is another abundant kind with large black crystals 3377 . - I saw a few fragments of a true Trachyte with large Crystal of glassy fractured Feldspar.

The lateral streams, joined the principal ones by a succession of Cascades. I looked at this scenery with real interest. - I believed I here saw the effect of running water, continued through so long a succession of ages, as to suffice to wear away, several thousand ft: in thickness of solid strata. - I do not say that the mouth of the valley, \& its higher parts were nothave never been acted on by the waves of the sea: but often, in the Cordilleras ... having attributed so much power to this latter kind of action, it was very satisfactory to see that form of valley, where I could believe, that the more ordinary agent of running water had been the efficient one. (DAR 37.798-801.) (Capitalisation and punctuation as in original. The four-digit numbers are those of rock specimens.) 


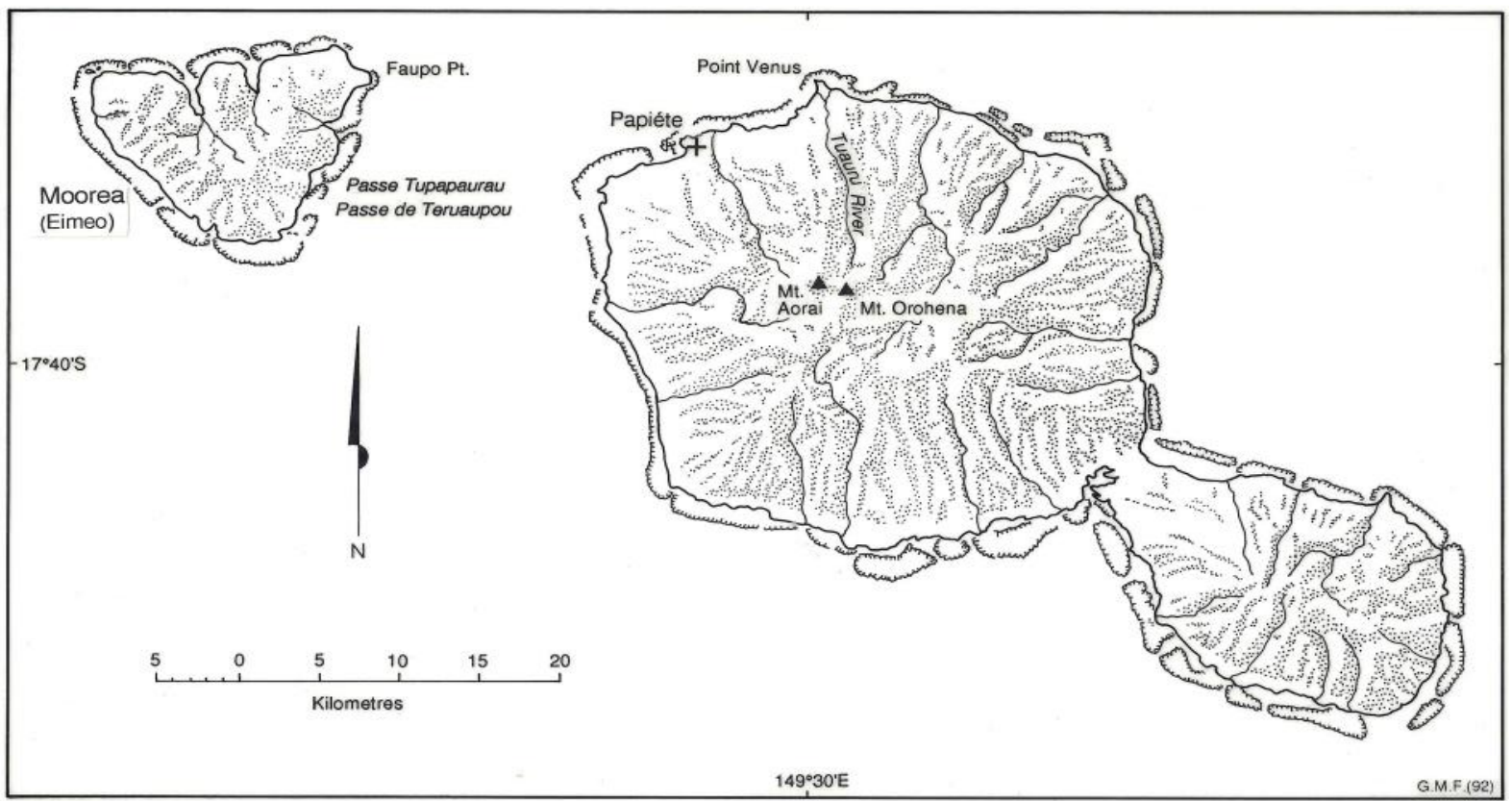

Figure 4. Map of Tahiti, showing the main island, and Moorea, that Darwin gained inspiration for the coral atoll theory

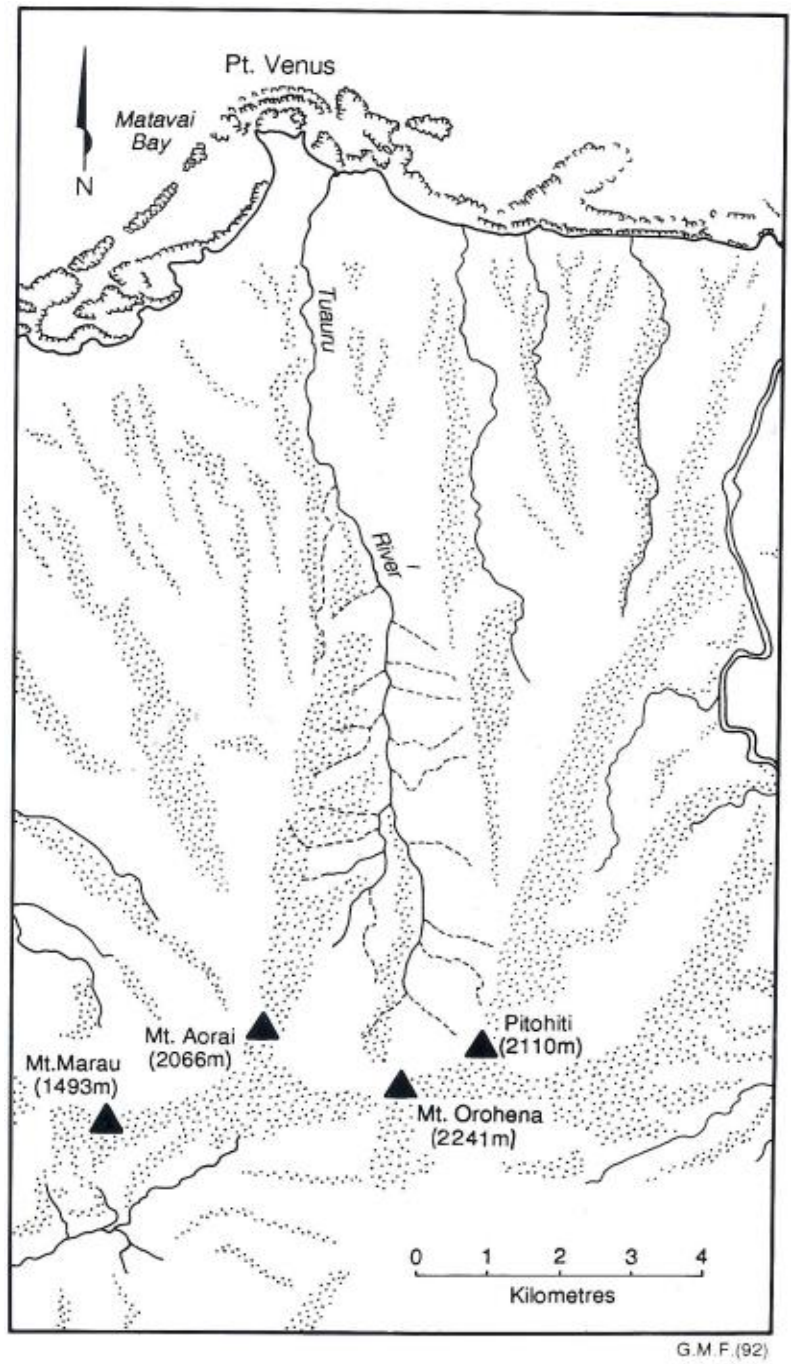

Figure 5. Map of the Tuauru Valley, Tahiti, explored by Darwin in October 1835.
The style is slightly improved and additional detail included (eg the columnar nature of some of the lavas). He compares the topography with the Cordilleras of the Andes visited a few months before, and in his speculations about marine action hint at changes in sea level. But the two passages are recognisable - the 'nests of olivine', the layers of 'grey lava', the trachyte and the feldspar, the eating away of the rocks by water action appear in both. He seems to have changed his mind about the identity of the hornblende crystals, they have become 'large black crystals'! Ultimately much of the material was included in chapter 2 of Volcanic Islands, vol. 2 of The Geology of the Voyage of the Beagle (1844) [12], the style further much improved.

Similarly, here are brief notations from the Galápagos note-book $(N B)$, concerning the terrestrial iguana, and one of Darwin's first annotations on the famous finches (figure 9):

$14^{\text {th }}$ [October 1835] Wandered about Bird collecting Iguana shakes head vertically; sea - one no $=$ dozes, hind legs stretched out walks very slowly - sleeps closes eyes Eats much cactus: Mr Bynoe [the ship's surgeon] saw one run walking from two other carrying it in mouth - Eats very deliberately, without chewing - small Finc[h] picking from same piece after alights on back - $(N B$, pages $42 \mathrm{~b}, 43 \mathrm{~b})$

These found their way into the Zoology Diary, as follows:

They are torpid slow animals, crawling when not frightened with their belly \& tail on the ground.frequently they doze on the parched ground, with their eyes closed \& hind legs stretched outwards.- In none of their motions, is there that celerity \& smartness which is so conspicuous in true Lacertas \& 
Iguanas.- Their habits are diurnal: they seldom wander to any distance from their burrows: when frightened they rush to them with a most awkward gait: excepting going down hill their motion, from the lateral position of their legs, is not quick. - They are not timorous. When attentively watching an intruder they curl their tails, \& raising themselves as if in defiance on their front legs, vertically shake their heads with a quick motion.- I have seen small Muscivorous Lizards perform the same gestures. This gives them rather a fierce as[pect], but in truth they are far to the contrary. When however ... being caught \& plagued with a stick they will bite it severely. - Two being placed on the ground together will fight $\&$ bite each other till blood is drawn.-

As I have said they all inhabit burrows, these they make sometimes between the fragments of Lava, but more generally in the ground, composed of Volcanic Sandstone.- The burrows do not appear deep \& enter at a small angle: hence when walking over the "warrens" the soil perpetually gives way.- When excavating these holes, the opposite sides of the body work alternately; one front leg scratches at the earth for a short time \& throws it towards the hind. This latter is well placed so as [to] heave the soil beyond the mouth of hole.- the opposite side then takes up the task.- Those individuals \& they are the greater number, which inhabit the extremely arid land, never drink water during the whole year.- They eat much succulent Cactus, which is in evident high esteem. When a piece is thrown towards them, each will try to seize it and carry it away as dogs do with a bone.[339] They eat however deliberately, without chewing the pieces.- The Cactus is in request amongst all animals, I have seen little birds at the opposite end of a piece which a Lizard [ie an iguana] was eating \& afterwards hop on with complete indifference on its back (DAR 30.295-296).

There is much that is typical of Darwin in the above: the eye for detail and the close observation; something of an ecological approach in his comments on habitat and food sources; a willingness to conduct simple experiments; a comparative approach; an emphasis on the behaviour of the organism - agonistic display and posturing, gait, burrow-excavation and feeding are described.

In the following case, the material from the little note-book seems to have been reused in the Diary as well as the Zoology Diary:

October 9. [There are] infinite numbers of the large yellow herbivorous Lizard, mentioned at Albermarle Isd [Isabela]. The burrows of the animal are so very numerous that we had difficulty in finding a spot to pitch the tents. These lizards live entirely on vegetable productions; berries, for which they frequently crawl up the trees, especially a Mimosa; never drinking water, they like much the succulent
Cactus, \& for a piece of it they will, like dogs, struggle [and] seize it from another...

This note was clearly used in compiling his descriptions in the book that became The Voyage of the Beagle (first published 1839). The Reptiles volume of Zoology of the Voyage of the Beagle (vol. 5, Darwin and Bell, 1843)[13] gives a brief account of the appearance and taxonomy of this species (as Amblyrynchus Demarlii), with the cross reference:

A very interesting account of their habits \&c, is given by Mr Darwin in his delightful Journal of the Voyage of the Beagle, p.466 to 472 , to which the reader is referred.

Interestingly, there are no references to the marine iguana in the Galápagos little note-book. They seem to have been amongst the first creatures that Darwin saw, on Charles Island (San Cristabel) on 17 September 1835, and he recorded what were probably quite early impressions in the Diary:

The black Lava rocks on the beach are frequented by large (2-3ft [60-90cm]) most disgusting, clumsy Lizards over which they crawl \& seek their prey from the Sea. Somebody calls them "Imps of darkness". They assuredly become the land they inhabit.

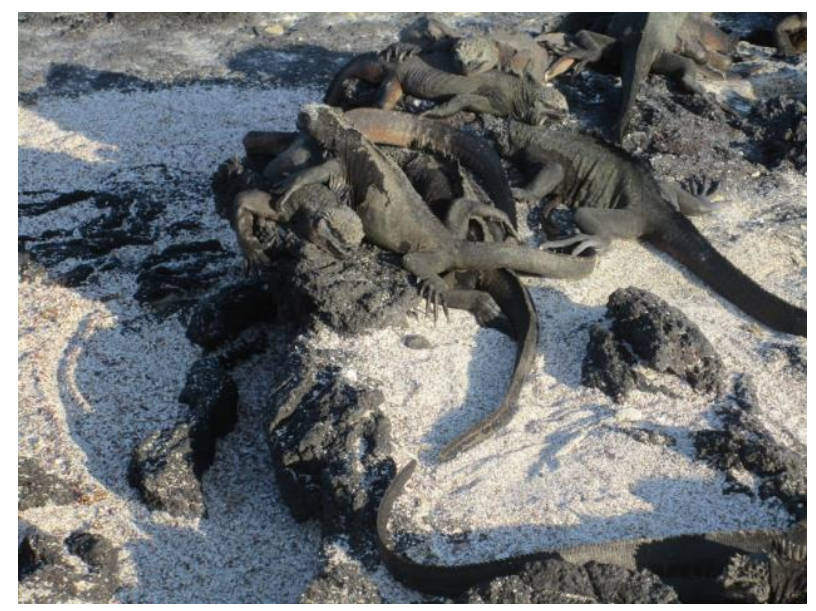

Figure 6. Marine iguanas, Amblyrhynchus cristatus (Bell) on lava.

These were the marine iguana (Amblyrhynchus cristatus, Bell), and they still swarm over the black lava on several of the islands (figure. 6). And the 'somebody' was Captain George Byron (later Vice-Admiral, the Lord George Anston Byron), cousin of the poet, who had visited two of the islands in March-April 1825 in H.M.S. Blonde, recording his observations in Voyage of HMS Blonde to the Sandwich Islands [14], a copy of which was aboard the Beagle. Darwin did a number of experiments with these creature, throwing them into the sea several times - they always swam back to close to their original place. On at least one occasion he weighed them down with a weight (the creatures survived). He also dissected several, and ascertained that their guts were full of seaweed, and that they were entirely herbivorous. 


\subsection{From the Field to Publication}

Some, but by no means all, the flows of observations (and ideas) from the little note-books, the Diary, and the Geological and Zoological Diaries are shown in figure 7. Publications on the ship, including Lyell's Principles of Geology, The Voyage of HMS Blonde, Humboldt's Travels, and Cook's Voyage contributed occasional material as Darwin compared earlier observations with his own. He was always comparing, not only his own observations in different localities, but also his ideas with those of others.

These notes and other documents were the raw material for the several publications that arose from the voyage. His
Diary, with the addition of other material ultimately became the Voyage of the Beagle, in some editions titled $A$ Naturalist's Voyage. The Geological Diary contained material that evolved into the Coral Reefs and Volcanic Islands books, volumes 1 and 2 of The Geology of the Voyage of the Beagle [15, 12]. Careful scrutiny of the texts of each can enable the identification the occasions when exactly the same words and phrases scribbled in the field, emerged, through a number of iterations, into publications a decade or so later (figure 7). Further consideration of this aspect is beyond the scope of this paper.

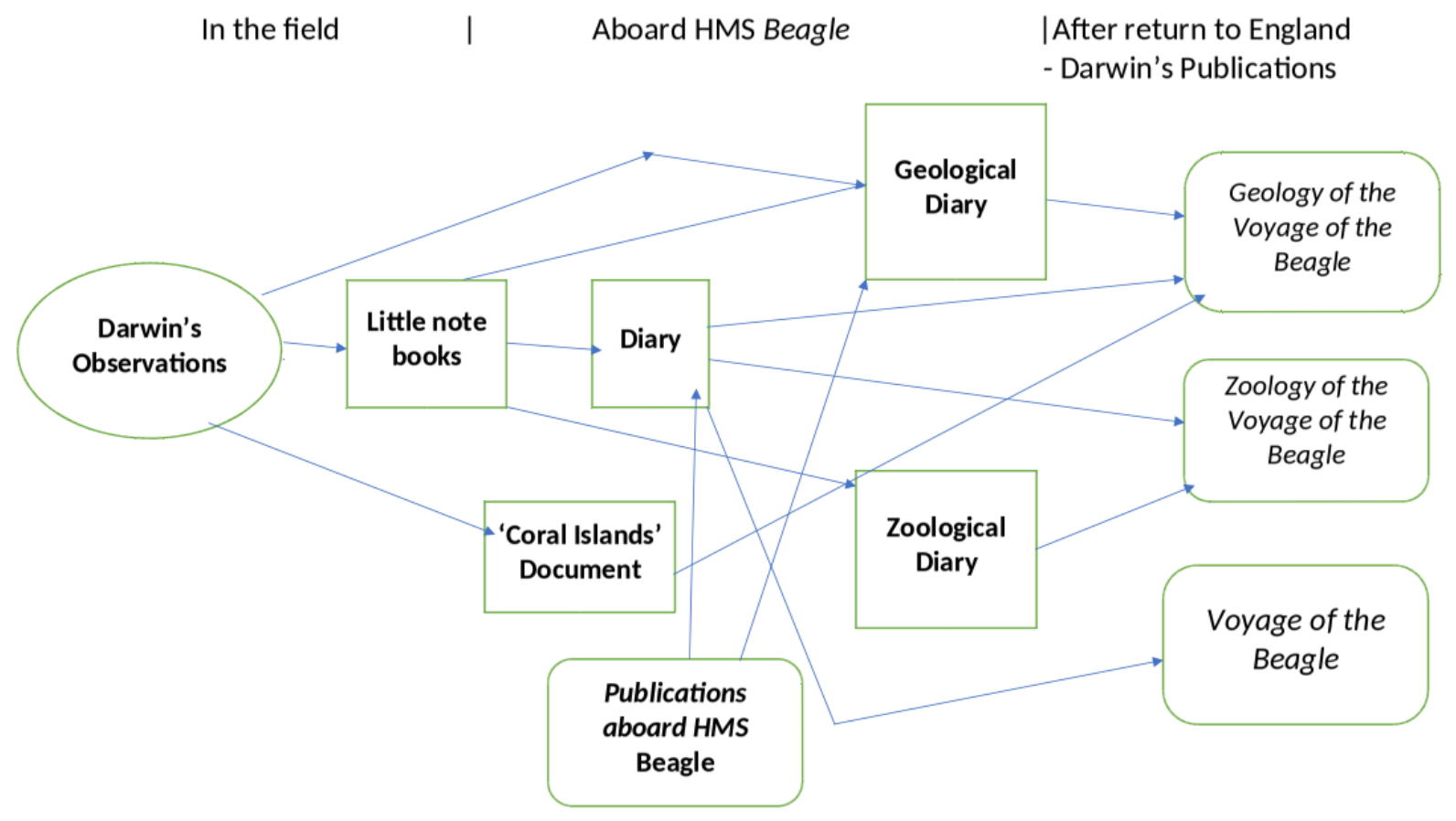

Figure 7. Flow of Darwin's ideas and observations from the Beagle period: from 'little note books' to final publications. 


\subsection{Themes from the Pacific Traverse - The Ecological Approach}

Throughout much of the voyage Charles Darwin carefully observed not only the appearance of organisms but the nature of their habitats, and the way in which they interrelated with one another. An eel was found in 'tidal pools' (Zoological Diary), insects were found 'under stones or dead birds or in rotting wood' (Smith, 1987), a Tahitian species of coral was 'Found in shallow water within the reef' (Zoological Diary, DAR 31.345). He described the 'impenetrable forests' of New Zealand, which had 'besides the Kauri ... Numbers of beautiful Tree-Ferns', the thick tropical forests of Tahiti, and the contrasting desert-like environments on some of the Galápagos Islands (figures 3 and 8), where the whole black Lava [was] completely covered by small leafless brushwood \& low trees' in the damper regions of some islands (Dairy 15 September 1835) and where the 'fragments of Lava where most porous, are reddish like cinders; the stunted trees show little signs of life'.

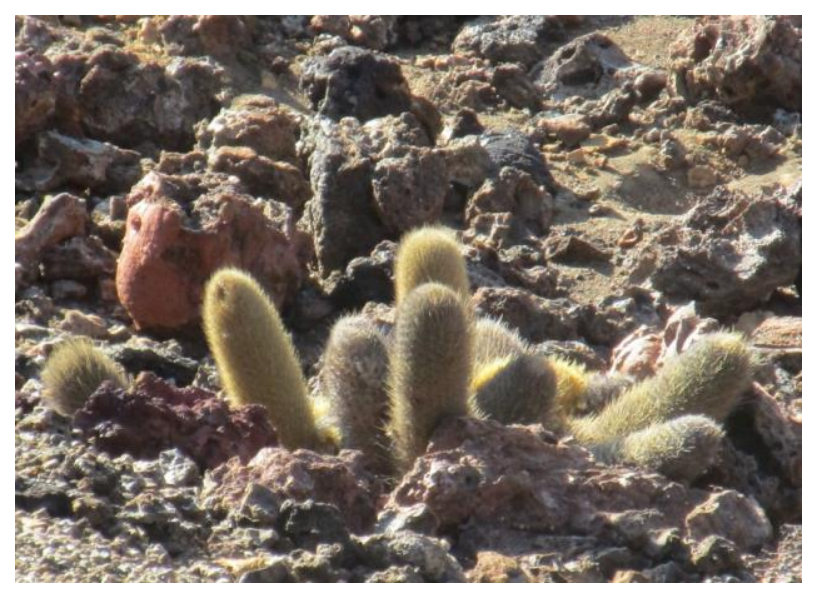

Figure 8. Lava cactus, Brachycereus nesioticus (K.Schum. ex B.L.Rob.) Backeb. A familiar sight on the open, desert-like, lava plains of the Galápagos

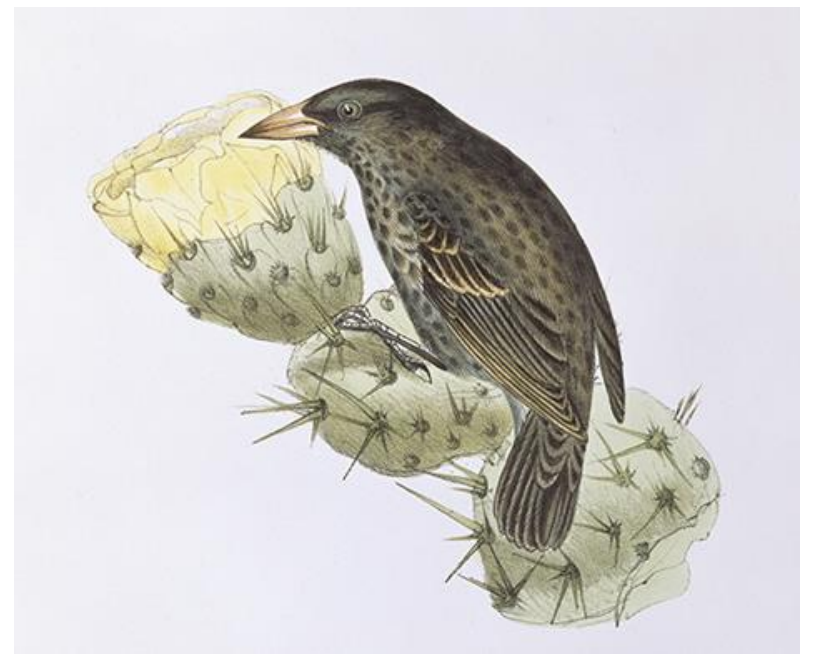

Figure 9. Cactus Finch (Geospiza scandens [Gould]). From The Zoology of the Voyage of the Beagle

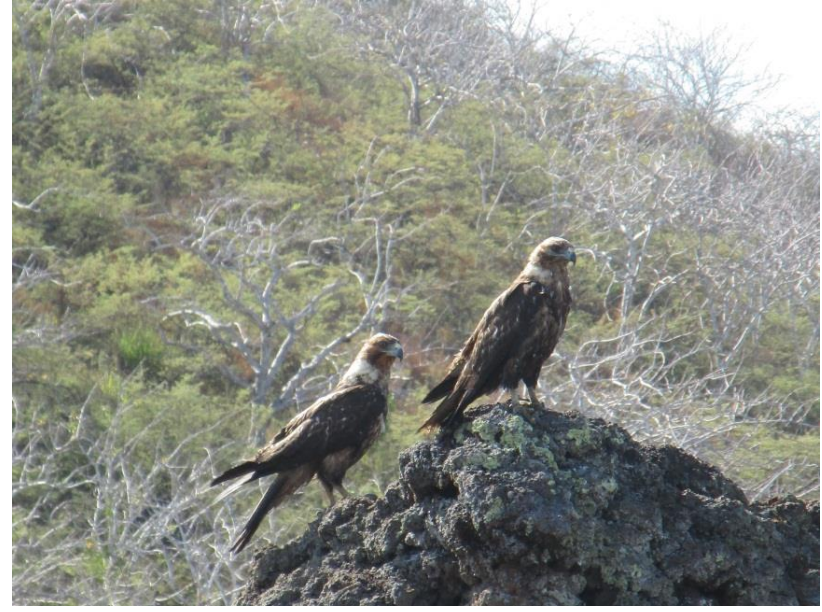

Figure 10. A pair of Galápagos hawks (Buteo galapoensis [Gould]).

He paid great attention to the food preferences of organisms: thus, he noted the manner in which marine iguanas ate seaweed (see above) and the terrestrial species ate cactus, berries and mimosa leaves. The occasional competition between individuals and possibly with finches (figure 9) for this food is also mentioned above. He speculated as to whether their natural enemies of the marine form might be sharks and marine creatures rather than land-bound predators. The enormous Galápagos tortoises (figure 11) also ate cactus as well as the "pale green filamentous lichen which hangs like tresses from the boughs of the trees' (DAR 31.329), and young tortoises, in their turn were taken by the Galápagos hawk (figure 10). A modern naturalist would be able to build a simple food-web diagram from data in Darwin's accounts.

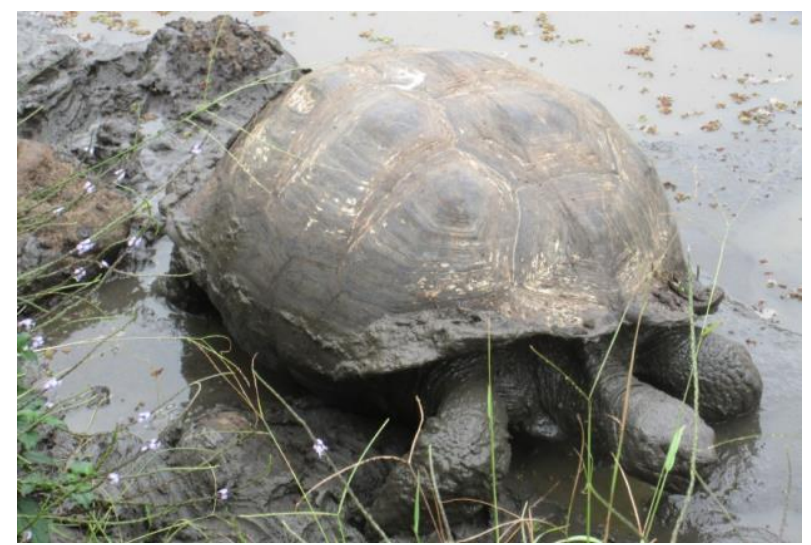

Figure 11. Galápagos giant tortoise (Geochelone, $\mathrm{sp)}$

Humans could be included in the web of food relationships: of the Maori people at the Bay of Islands he noted:

The whole country abounds with fern, \& the roots of this, if not very palatable, yet contains much nutriment. A native can always subsist on them \& on shell fish, which is very abundant on all parts of the sea shore (Diary, 23 December, 1835).

In Tahiti, he comments quite extensively on the way the 
indigenous people are able to 'live off the land', consuming wild fruits and roots of several species, fish and 'eel and crayfish'.

Notions of food-chains and food-webs and the concept of the ecosystem lay far in the future, yet at this early stage in his career Darwin was seeing 'whole environments' and perceiving links between species. The notion of evolution through natural selection, expounded in On the Origin (1859) [16] is profoundly ecological one, and the fact that its author was using ecological conceptual frameworks over 20 years before its publication is of note.

\subsection{Animal Behaviour}

Little escaped the young naturalist in the field of the behaviour of organisms. The gait of several creatures is described in detail: he notes 'the quick and clumsy gait' of the terrestrial iguana (above), and studied the movement of the tortoises in some detail. The Galápagos little note-book $(N B)$ contains rudimentary calculations (page 51b). These were transformed in the Diary entry for October 9, 1835 into: 'I think they march at a rate of 360 yards in an hour; perhaps four miles in the 24'. The marine iguanas swam by means of 'wriggling motion of the tail and body' (DAR 31.335) sometimes up to 100 yards from land. He also noted of the terrestrial species that 'Their limbs are well adapted for crawling amongst the rough \& fissured rocks': a link being perceived between the behaviour and the habitat. The flight of frigate birds and their manner of diving on fish was described in detail (DAR 31.344).

The sounds that creatures made was often recorded: the tortoises hissed, and when copulating produced a 'hoarse roar' or 'bellowing' (DAR 31.331). He even found a fish that 'grunted', and a 'fine green' lizard at the Bay of Islands in New Zealand that lived in trees and 'is said to make a laughing noise' (Keynes, 2009 [17] and Zoology of the Voyage, vol. 5, Reptiles [13]).

The agonistic display of organisms - display related to fighting, aggression, or retreat and placation - was of special interest. The behaviour of an iguana when faced with an intruder was mentioned above, and compared to that of other reptile species. He also recorded species of Onchidium (sea slug) that he found in the Galápagos, which 'when irritated emits a milky sticky fluid' (Zoology Diary, DAR 31.323).

He was impressed by the extreme tameness of many creatures - comparing this with what he found in the Falklands, and later at the Cocos (Keeling) Islands. On about 12 October 1835 he noted in the little note-book (p $37 b$ ) that the giant tortoises 'will drink when a person is within 2 yards $[1.9 \mathrm{~m}]$ of them'.

A few days earlier he had noticed:

The birds are Strangers to Man \& think him as innocent as their countrymen the huge Tortoises. Little birds [presumably finches], within 3 or four feet, [approx. 1-1.3m] quietly hopped about the Bushes \& were not frightened by stones being thrown at them.
Mr King killed one with his hat \& I pushed one off a branch with the end of gun a large Hawke (Diary, 17 September 1835).

Darwin later wrote extensively on animal behaviour: there is a chapter on 'Instinct' in On the Origin, and The Expression of Emotions in Animals and Man [18] appeared in 1872. Some of the inspiration for these may have come from observations on the creatures of remote islands visited on the Beagle voyage. It is perhaps of interest that there was a copy of W. Kirby's Introduction to Entomology [19] aboard the ship, and evidence that Darwin referred to it. Kirby devotes considerable attention to the behaviour of insects. See also Armstrong, 1993 [19].

\subsection{Island Biodiversity and Biogeography}

From an early stage of the voyage Darwin noticed that the natural history of islands and island groups was distinctive (at least after visiting St Paul's Rocks in the Atlantic, 15 February 1832, see Armstrong, 2004) [5], and after visiting the Galápagos his declaimed 'the zoology of archipelagoes will prove worth examining'.

He noticed that the biota of an island was often depauperate. Although in Tahiti he had much to say about the lushness of the vegetation, and the profusion of the tropical forests, he observed:

It must not be supposed that these woods equalled the forests of Brazil in an island that vast number of productions which characterise a continent cannot be expected to occur (Diary 17 November 1835, his first full day on the island).

Darwin was perceptively distinguishing between the thickness or denseness of the forest and the variety of plant species that made it up; a modern ecologist would distinguish the biological productivity of the ecosystem from its biodiversity (the passage above was probably written up some days later, after he had had time to consider the vegetation more extensively).

In New Zealand he observed:

In the woods I saw very few birds: with respect to animals [ie mammals] it is remarkable that so large an island extending over nearly a thousand miles of latitude, \& in many parts one hundred \& fifty broad, with varied stations \& land of all heights from 14,000 feet [an overestimate] downwards should not possess on indigenous animal with the exception of a small rat (Diary 24 December 1835).

Several times on the Pacific traverse he comments on the absence of species he might have expected to see. He comments on the absence of both tree-ferns and humming birds in the Galápagos (albeit the latter annotation is on the verso of a page on Galápagos ornithology, and just might have been written later).

There are no notes on long-distance dispersal, and its irregularity, its fickleness and problematic nature, in the 
writings on the Pacific islands, although one is tempted to believe the notion must have been in Darwin's mind. It is hinted at obliquely in notes on the Cocos (Keeling) Islands in the Indian Ocean visited some months later (Armstrong, $1991,1992,2004)[1,5,22]$, and referred to in the On the Origin.

Although he was aware of the South American affinities of the Galápagos biota, particularly the avifauna, he also strongly suspected that many of the animal inhabitants were endemic. Of the two species of iguanas he observed:

I cannot help suspecting that this genus, the species of which are so well adapted to their respective localities is peculiar to this group of Isls. (DAR 31.339; italics mine.)

Relatively late in his sojourn in the islands he became aware of the differences in the biota of the various islands.

Mr Lawson states that he can on seeing a Tortoise pronounce with certainty from which Island they inhabit - (DAR 30. 338).

(Mr Lawson was an Englishman acting as Governor.)

At the time, Darwin assumed that the tortoises had been introduced from elsewhere and did not grasp the significance of this remark. It was only much later, after he had returned to England, that he appreciated fully the full significance of the differences between the avifauna (finches, mockingbirds) of the different islands, and the possible evolutionary significance of this. Today it is appreciated that each island has its own biota.

Darwin was fairly certain that Tahiti had been elevated, perhaps in the more remote past. Amongst his geological notes is the rather cryptic remark:

The Isd of Tahiti has existed as dry land for a long period.- Does this agree with any conclusion drawn from the geographical kinds of flora and Fauna? Does such indicate a distinct and ancient origin? (DAR 3. 801 , verso)

Some have read an evolutionary significance into this passage, but this is perhaps overindulgent, although he does seem to be implying that the Tahitian biota is distinctive. And he also refers to the Galápagos as a "centre of creation'. It does not seem that while on the Pacific islands or immediately after he was adopting an evolutionary approach. Moreover, a careful study of Darwin's Beagle notes from the Galápagos period does not suggest any sudden flash of insight during his sojourn on the islands.

\subsection{Vulcanicity, Time and Erosion}

Darwin was intensely interested in the form, landscape or geomorphology of volcanic islands, particularly in the Galápagos. He noticed the manner in which volcanic cones protruded from the more-or-less level nature of parts of the landscape, as has been mentioned above. He was particularly impressed by some of the volcanic craters he encountered. 'To the South of the Cove I found a most beautiful Crater, elliptic in form, less than a mile in its longer axis \& about 500 feet deep. Its bottom was occupied by a lake, out of which a tiny Crater formed an Island. The day was overpoweringly hot: \& the lake looked bright \& clear. I hurried down the cindery side, choked with dust, to my disgust on tasting it found it Salt as brine' (Diary 1 October 1835). A few hundred metres to the north is another rather similar crater lake, which Darwin also possibly visited; it has no internal cones or islands, and is sometimes regarded as more picturesque and 'visitor-friendly': it is named Darwin Lake (figure 12).

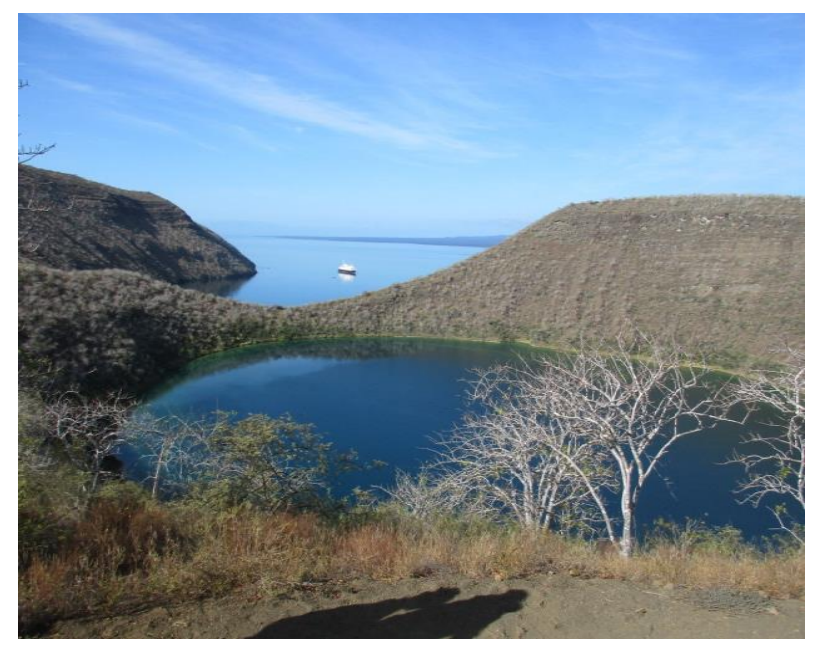

Figure 12. Darwin Lake: a salt lake in a volcanic crater, Albemarle Island (Isabella)

Darwin was interested in the geological age of the volcanic forms, and their relationship to each other; in his description of the lava follows near Buccaneer Cove on James Island (Santiago) from the Geological Diary, in early October 1835 he remarked:

I should suppose all these Lavas have been ejected at one eruption epoch of activity: small intervals of time separating these streams.-

However, he saw that some flows and volcanic cones and craters were somewhat more recent than others. He described the manner in which the low volcanic cones stand out from the generally rather flat expanses of the lava flows, identifying the range of ages:

From one point of view I counted 60 of these truncated hillocks, which are only from 50 to $100 \mathrm{ft}$. above the plain of Lava. The age of the various steams is distinctly marked by the presence \& absence of Vegetation: in the latter \& more modern nothing can be imagined more rough or horrid.

Darwin constantly compared the rocks, landforms and organisms of one locality with those of others. Landforms and rock-types close to the Bay of Islands, North Island, New Zealand (figure 13) were similar to those of the Galápagos: 
The soil is volcanic, in several parts we passed over shaggy are vesicular lavas, $\&$ the form of a crater was clearly distinguished in several of the neighbouring hills (Diary, 23 December 1835).

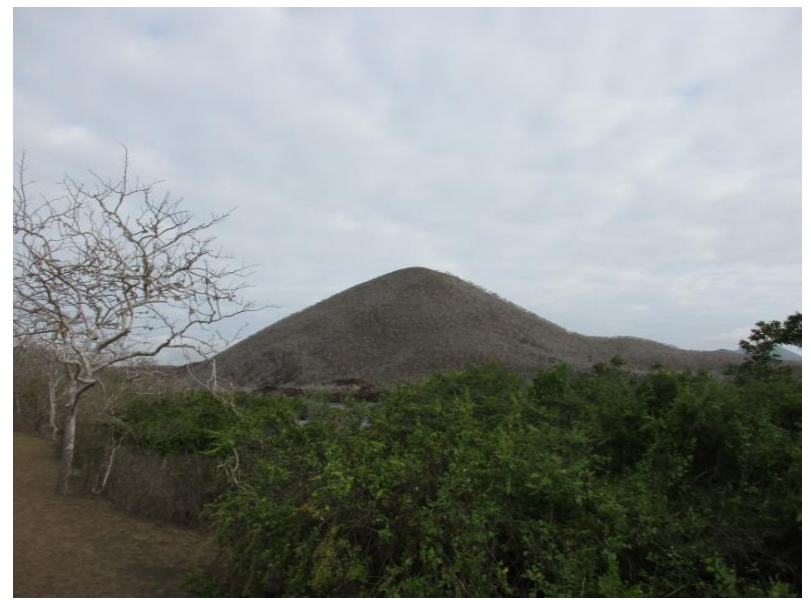

Figure 13. 'Truncated hillocks ... above a plain of lava'. North Island New Zealand.

Several specimens of volcanic rocks were collected at the Bay of Islands, North Island, New Zealand.

At both the Galápagos and Tahiti he comments on the great thicknesses of volcanic material, and therefore the long period over which they must have accumulated; nevertheless, he realised that volcanic forms were just temporary phenomena, and volcanic islands were subject to destruction:

At Banks Cove the Beagle was anchored within a Crater larger even than one described [...], but in a much more demolished state. ... The highest part is about $700 \mathrm{ft}$ [220m]; the external sides, instead of affording a gentle slope, have been weathered by the sea into bold cliffs.

From an early moment after his arrival at Tahiti he appreciated that the island was composed of great thicknesses of volcanic lavas. He looked in vain for a crater, soon realizing that it had long since been eroded away:

I may remark that the form of the land renders it probable that no crater could at the present be found.

But while erosion in the Galápagos was at least partly by wave attack, in Tahiti, erosion was subaerial, by rivers and streams. First however, the rocks were weathered. He continued: 'All the lavas have undergone decomposition to a remarkable degree - Hence the great thickness of Wacke'. [Wacke $=$ a poorly sorted sandstone containing fragments of rock and minerals in a clayey matrix, in this case as the result of prolonged tropical weathering.]

On the next page of his notes:

The highest mountains are worn into some of the most extraordinary precipitous outlines which I ever did behold. The characteristic feature of this scenery is the depth and narrowness of the sides of the valleys or rather mountain gorges.- The main one which I ascended, in its highest part scarcely ever exceeded in its breath the width of the torrent... it was very satisfactory to see that the form of the valley, where I could believe the ordinary agency of running water had been the efficient one. ... I looked at this scenery with great interest. I believed I saw the effect of running water, continued through so long a succession of ages, as to suffice to wear away several thousand $\mathrm{ft}$ in thickness of solid strata (DAR 37.300).

He summarized:

[The island] after being raised was cut by numerous profound ravines, which all diverge from a common centre; the intervening ridges this belonging to one slope $\&$ being flat topped.

Volcano and crater formation, possibly relatively abrupt, although possibly occurring over a period, was followed by 'decomposition'. Weathering on Tahiti of the lavas into 'wacke' was associated with severe erosion by running water, leaving sharp ridges, deeply incised valleys, steep precipices, and isolated rocky peaks. In the Galápagos he saw evidence of demolition by marine action. Uniformitarian Charles Lyell (whose Principles of Geology [1831-36] [20] Darwin had with him aboard) had emphasized the long-continued action of the gradual processes of erosion and deposition. But it is interesting to consider Darwin moving towards utilizing similar ideas at this early moment in his career. We can see Darwin absorbing here, ill-formed perhaps though they be, aspects the gradualist imperative that was later to serve him so well.

\subsection{Sea Level Change and the Theory of Coral Reefs and Atolls}

In South America Darwin had found fossil marine shells high in the Andes, and apparent marine terraces well above sea level in Peru. There is some evidence that he thought about sea level change while at the island of Chiloé, off southern Chile (Armstrong, 2004) [5]. There are some hints that he was thinking about coral reefs during his sojourn in South America in the Santiago little note-book, although the dating of these entries is a little uncertain (Chancellor \& van Wyhe, 2009) [9].

As in Pacific a Corall bed forming as land sunk. Would abound with those genera which live near the surface. (mixed with those of deep water)...

Is there a a large proportion of these Coralls which live only near surface.- If so we $\&$ may suppose land sinking: ...

The Coral theory rests on the supposition of depressions being very slow $\&$ at small intervals... (Santiago NB, pages 95-97, and 120)

And there is a letter, dated 25 June 1835, from a Mr R E Allison, who had helped with some of Darwin's work in 
Chile, saying he was looking forward to Darwin's reports from the Pacific Islands: 'It will' he stated, ' be curious if you find sinking of land there \& rising here'. Darwin at the time was at Copiapó (DAR 36.1: 427-427a and Burkhardt and Smith, 1985) [23].

$\mathrm{He}$ searched in vain for much evidence of vertical movement in the Galápagos, but, as has been shown above, he was convinced that Tahiti had risen. He went on to write of deposits of marine shells appreciably above beach level in New Zealand, but wondered whether they were natural of the result of the activities of the Maoris. Later still, in Australia he was convinced in his own mind (wrongly) that the valleys of inland New South Wales had been cut by marine action (Armstrong, 1993), [24]. The notion of sea level change - the possibility of both rises and falls of the land in relation to the present datum - was constantly in his mind for much of the last year and a half of the voyage. (Strangely he did not identify the long inlets of southern Australia such as Sydney Harbour, the Derwent Estuary [Tasmania], Princess Royal Harbour [Western Australia], as submerged valleys.)

He had read about coral atolls in Lyell's Principles of Geology, and some of the other books giving accounts of previous voyages that were held on the Beagle, and was keen to see one for himself. His chance came on 13 November 1835.

The width of the dry land is very trifling: from the Mast-head it was possible to see at Noon Island across a smooth lagoon to the opposite side. This great lake of water was about 10 miles wide. (Diary)

At Tahiti he explored the surrounding coral reefs very thoroughly, noticing the form of the individual species of coral (and the fact that different species existed in different parts of the reef). He also had access to Captain FitzRoy's hydrographic data that had been accumulated. It was clear that offshore the sea bed sloped away extremely steeply.

On 17 November 1835, while Captain FitzRoy and some of his officers were making navigational observations, Darwin ascended a nearby summit close to Fore Topato, $872 \mathrm{~m}$, in altitude. From there he looked due west:

From this point there was a good view of the distant island of Eimeo [now named Moorea] ... On the top of lofty and broken pinnacles, white masses of clouds were piled, which formed an island in the blue sky, as Eimeo itself in the blue ocean. The island is completely circled by reef, with the exception of one small gateway. At this distance a narrow but well defined line of brilliant white, where the waves first encountered the wall of coral, was alone visible. Within this line was included the smooth glassy water of the lagoon, out of which the mountains rose abruptly, the effect was very pleasing \& might aptly be compared to a framed engraving, where the frame represents the breakers, the marginal paper the lagoon, $\&$ the drawing the Island itself. (Diary)

Amongst the notes in the Geological Diary in in
Cambridge, is a manuscript (now at DAR 40.1-22, and reproduced in Stoddart, 1962) [25]. entitled Coral reefs. Its precise date has been the subject of debate, but from internal evidence it must have been written after the Tahiti visit, and indeed much of it after 3 December 1835 (see below).

In this essay, the view of Eimeo is briefly re-described, and combined with his work on the shores of the main island of Tahiti:

The mountains rise out of a glassy lake, which is separated on all sides, by a narrow defined line of breakers, from the open sea. Remove the central group of mountains, \& there remains a Lagoon Isd [ie atoll]. I ground this opinion from the following facts. There is a general similarity in the two cases in the form \& size of the reefs; their structure appears identical, we have scarcely fathomable water in each case, at a very short distance on the outer margin; within is a shallow basin more or less filled by knolls of growing coral or converted into dry land. In the Lagoon Isds there are some which do not deserve this title for they consist solely of a circular reef of which scarcely a point projects above water: while others are more or less complete, but narrow ring of land (DAR 40.5).

Descriptions of the small-scale features of the reef and lagoon are integrated into the account; he notes (from his fieldwork in Tahiti) how an outer 'mound' or 'breakwater' of living coral slopes inwards towards the 'glassy lake' of the lagoon. The waves, breaking violently on the outmost edge, pump water in sheets over the reef. 'Hence the surface is worn smooth \& and gently declines toward the lagoon.' (DAR 40.12). He also drew attention to the fact that coral growth (by certain specialised forms of coral) was most vigorous at the outermost edge, speculating, quite correctly, that this might be because of the movement of the water 'or the quantity of insolved air'.

On 26 November 1835 H.M.S. Beagle, according to the Diary, 'passed near the island of Whylootacke'; Captain FitzRoy also refers to 'Waiutaki': the modern name is Aituaki (figure 14). It is one of the Cook Islands. FitzRoy was supplementing his notations with details from elsewhere, and went on:

[It is] a small group of islets encircled by a coral reef, from four to eight miles in diameter. The principal one is 360 feet high, and nearly four miles long (Narrative of the Surveying Voyage, page 557).

Darwin was enthralled, and gives extra details: We saw here a union of two prevailing types of structure ... A hilly irregular mass was surrounded by a well defined circle of reefs, which in great part have been converted into narrow strips of land, which as Cook calls them are half drowned, consisting of merely of sand \& Corall $[s i c]$ rocks heaped up on the dead parts of the former reef. 
Darwin almost certainly climbed to the masthead again, and in using the term 'half-drowned' suggests that was now adopting the idea that coral atolls were formed by the gradual submergence of a volcanic peak as the result of a rise in sea level, or fall in the level of the land. A fringing reef, developed into a barrier reef, and as the volcanic islet disappeared, into a circular, oval or horseshoe-shaped atoll (figures 15, 16). Aituaki occupies an intermediate position: it has the form of an atoll, but remnants of the original volcanic islet remain. Charles Darwin in the traverse of the Pacific had thus seen the volcanic islands of the Galapagos, places on Tahiti where fringing reef comes close to the shore, the 'atoll with remnants' at Aituaki, and the well-formed atoll of Noon Island seen earlier.

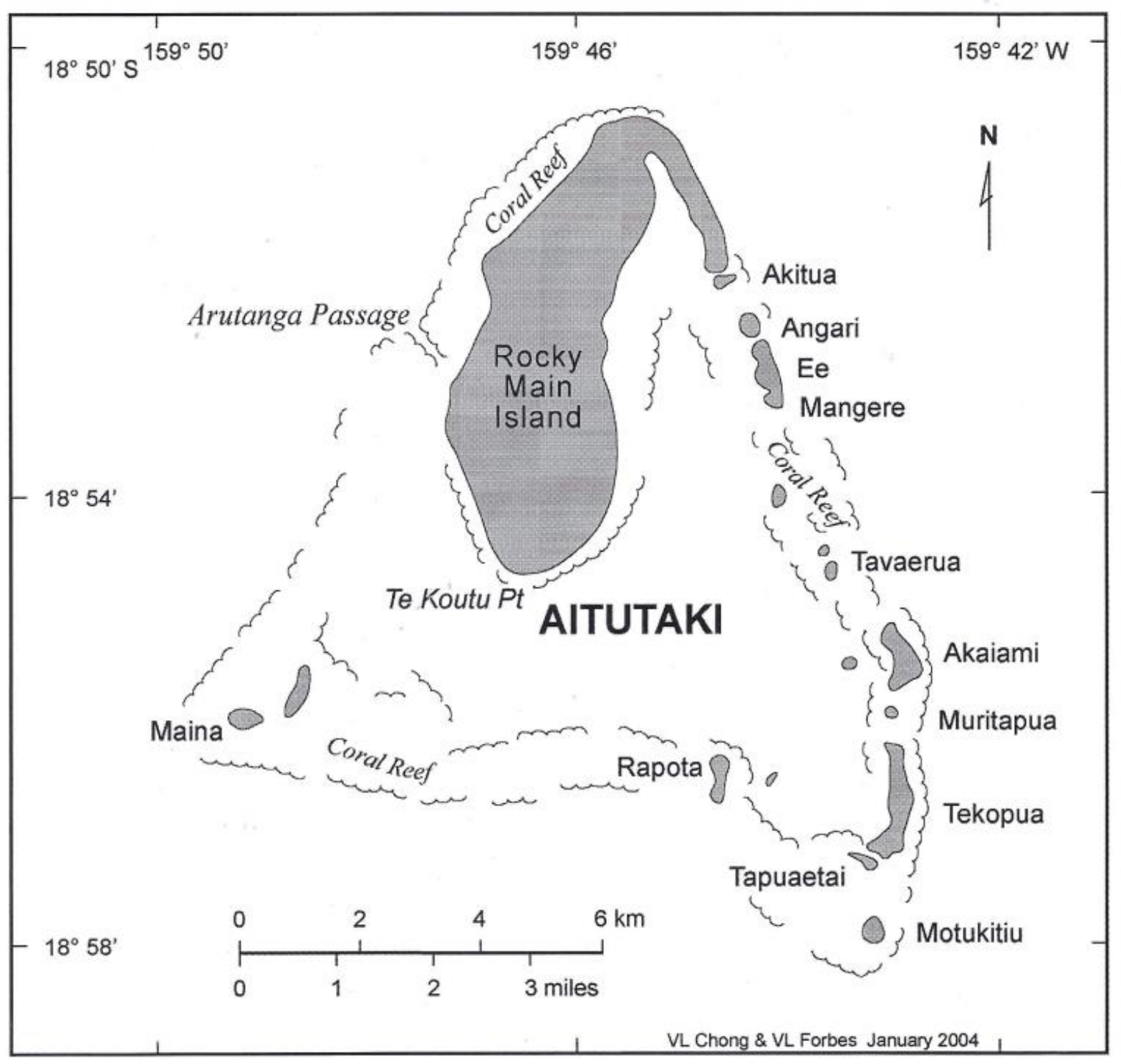

Figure 14. Map of Aituaki, Pacific Ocean (now part of the Cook Islands). 

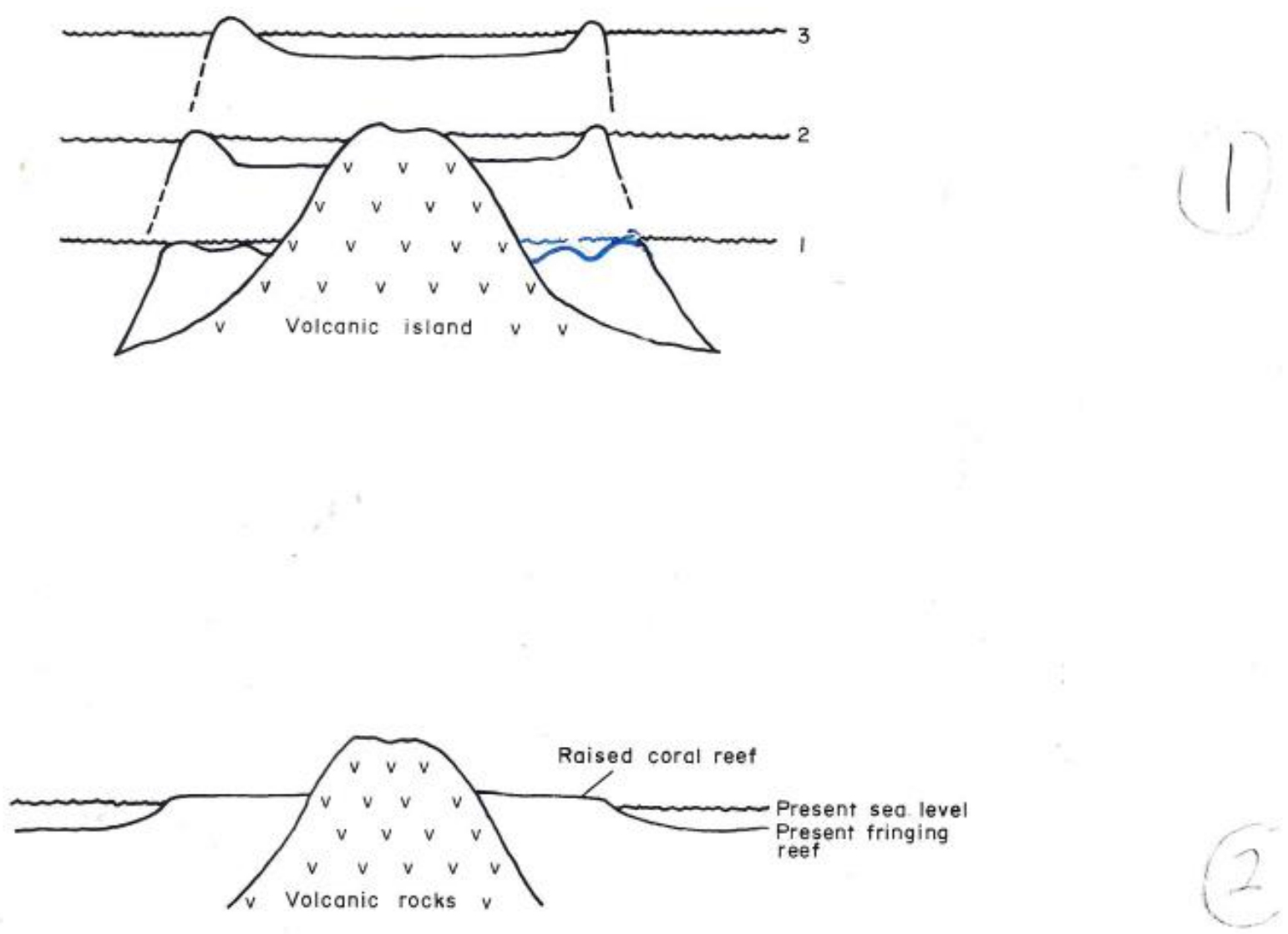

Figure 15. Darwin's theory of coral reefs and atoll. As the result of a change in sea level, a fringing reef is transformed into a barrier reef and eventually into an atoll. Below: a cross section of a barrier reef.

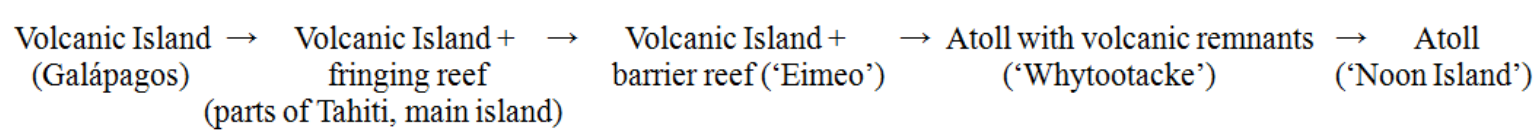

Figure 16. Darwin's 'Theory of coral reefs and atolls', showing the gradual transition of one form into another, illustrated from islands Darwin saw on the Pacific traverse.

The coral atoll theory was thus more or less complete by the time the Beagle arrived in Port Jackson (Sydney) in January 1836: its development was more or less coincident with the Pacific transect: it had provided Darwin with examples of most stages in the sequence. But this was not the end of the story: three months later, in April 1836, Darwin set foot on a true atoll for the first time, at the Cocos (Keeling) islands in the tropical Indian Ocean: he was able to confirm the appropriateness of his model (Armstrong, 1991, 2004, 2015) [1, 5, 22]. Later still, in May, a short visit to Mauritius gave him further information on fringing reefs and provided an example of where there had been emergence of the land relative to the sea rather than subsidence. And after the three-week sojourn at the Cape of Good Hope were the Atlantic volcanic islands of Ascension, St Helena, the Cape Verde group and the Azores. Further information was gathered at all these points, and in the sea journeys between them annotations were ofttimes placed on his existing notes as he compared his observations in the different island groups.

The 'Coral Islands' essay, written at sea during the later stages of the traverse, evolved into Darwin's first substantial scientific paper, given before the Geological Society (1837) and then into the Coral Reefs volume of The Geology of the Voyage. Geological observations from the Galápagos, Tahiti and New Zealand were published in the companion Volcanic Islands volume.

\section{Conclusions}

The Pacific traverse does indeed represent a 'high point' in the voyage for Darwin. He had been honing his skills of observation, note-taking and collecting for over three years. He knew what he was doing. By now he as a convinced Lyellian: he understood about geological time. His notes on both the Galápagos and Tahiti show that he realised that 
just as volcanic activity built up islands, the processes of wave action, and the long-continued work of running water eroded, destroyed and removed themxs. He found evidence of both rising and falling sea levels (or land levels). His extremely imaginative development of the coral atoll theory was his first substantial adoption of the Lyellian notion of gradualism in the development of a coherent explanatory framework. It depended on his grasping idea of sea level change, which had been in his thoughts for many months. The traverse provided the substance for his first scientific paper, and core of the material for two of the volumes of the Geology of the Voyage, and much for three of the volumes of the Zoology of the Voyage. He was paying attention to the behaviour of animals, as well as their appearance and structure. He also placed organisms in their setting, looking at their food-relationships and habitat, sometimes seeing relationships between their ecology and behaviour: the word adaptation, so important in later his evolutionary writings was beginning to creep into his vocabulary.

But it would not be true to say that it was just 'the Pacific that made Darwin' (see the quotation on the first page of this paper). In the final days of the voyage he wrote:

[A]s a number of isolated facts soon become uninteresting, the habit of comparison leads to generalization... (Diary, after 24 September 1836)

The very briefest examination of Darwin's notes allows the reader to appreciate the extent that Darwin's abilities lay in his 'habit of comparison'. He constantly re-read his notes, adding comments. The geological observations on one island would be set against those of another (he generally wrote on one side of the paper only leaving the verso for later additions and comments). The observations on the geology of the Galápagos were considered alongside those from the Cape Verdes, Ascension, St Helena, the Azores and Tahiti. The theory of coral reefs was generated in the Pacific, but only confirmed after his fieldwork on Cocos and Mauritius in the Indian Ocean. The Galápagos provided the behaviour of the iguanas and tortoises, but other important observations on behaviour were made in the Falklands for example on the Caracara (hawk), the Magellan penguin and the steamer duck (Armstrong, 1992a [26].

The Pacific did indeed have a profound influence on Darwin's development, but it must be seen in the context. He actually had his feet on six islands between Callao and Port Jackson (although he had good views of over a dozen others). He seems to have landed on about 40 islands during the whole voyage: he carried, and developed, ideas as he went, alongside his specimen collections and notes.

\section{REFERENCES}

[1] Armstrong, P. H., "Charles Darwin's Indian Ocean experience", Journal of the Royal Society of WA, 98(1),
2015, 1-8

[2] Macleod, R. and Rehbock, P. F. (Eds), "Darwin's Laboratory”, Honolulu: University of Hawai'i Press, 1994.

[3] Armstrong, P. H., "Charles Darwin's Visit to the Bay of Islands, New Zealand, 1835". Auckland Historical Journal, 60, 1992, 26-29.

[4] Armstrong, P H., "Charles Darwin's Perception of the Bay of Islands, New Zealand, 1835 ”, New Zealand Geographer, 49(1), 1992, 10-24.

[5] Armstrong, P. H.. "Darwin's Other Islands". London: Continuum, 2004.

[6] Estes, G., Grant, K. T. and Grant, P. R., "Darwin in the Galápagos: His Footsteps through the Archipelago", Notes and Records of the Royal Society of London, 54(3), 2000, 343-368.

[7] Grant, K. T. and Estes, G. B., "Darwin in the Galápagos: Footsteps to a New World", Princeton and Oxford: Princeton University Press, 2009.

[8] Barlow, N. (Ed.), "Charles Darwin's Diary of the Voyage of H.M.S. Beagle". Cambridge University Press, 1933. This Diary was the basis of the book now known as "The Voyage of the Beagle", in some editions titled "The Voyage of a Naturalist".

[9] Chancellor, G. and van Wyhe, J., "Charles Darwin's Notebooks from the Voyage of the Beagle", Cambridge University Press, 2009.

[10] Smith, K.G.V. (Ed.), "Darwin's Insects: Charles Darwin's Entomological Notes", Bulletin of the British Museum (Natural History), 14(1), 1987, 1-143.

[11] Darwin, C. R. (Ed.), "The Zoology of the Voyage of H.M.S. Beagle, Part 3, Birds, by John Gould, London: Smith Elder and Co, 1841.

[12] Darwin, C. R., "Geological Observations on the Volcanic Islands Visited during the Voyage of H.M.S. Beagle, together with some brief notices of the geology of Australia and the Cape of Good Hope. Being the second part of the Geology of the Voyage of the Beagle, under the Command of Capt. Fitzroy, R.N. during the years 1832 to 1836", London: Smith Elder and Co, 1844.

[13] Darwin, C. R. (Ed.), "The Zoology of the Voyage of H.M.S. Beagle. Part 5, Reptiles, by Thomas Bell", London: Smith Elder and Co, 1843.

[14] Byron, G. G., Baron, "Voyage of H.M.S. Blonde to the Sandwich islands, in the years 1824-1825". London: John Murray, 1826.

[15] Darwin, C. R., "The Structure and Distribution of Coral Reefs. Being the first part of the Geology of the Voyage of the Beagle, under the Command of Capt. Fitzroy, R.N. during the years 1832 to 1836 ", London: Smith Elder and Co, 1842 .

[16] Darwin, C. R., "On the Origin of Species" London: John Murray, 1859.

[17] Keynes, R. (Ed.), "Charles Darwin's Zoology Notes and Specimen Lists from the Voyage of H.M.S. Beagle", Cambridge University Press, 2009.

[18] Darwin, C. R., "The Expression of the Emotions in Animals 
and Man” London: John Murray, 1872.

[19] Kirby, W. and Spence, W., "An Introduction to Entomology", London: Longman, Brown, Green, Longmans and Roberts,1815. Many subsequent editions.

[20] Lyell, C., "Principles of Geology: being an attempt to explain the former changes of the Earth's surface, by reference to causes now in operation", London: John Murray, (3 vols) 1830-1833.

[21] Armstrong, P. H., "An ethologist aboard H.M.S. Beagle", Journal of the History of Behavioural Science, 29(4), 1993, 339-344.

[22] Armstrong, P. H., "Under the Blue Vault of Heaven: an Account of Charles Darwin's Sojourn in the Cocos (Keeling) Islands", Nedlands, Western Australia: Indian
Ocean Centre, 1991.

[23] Burkhardt, F. and Smith, S. (Eds), "The Correspondence of Charles Darwin”, vol. 1: 1821-1836, Cambridge University Press, 1985.

[24] Armstrong, P. H., "The Contrasting Views on the Australian Valleys of Charles Darwin and James Dwight Dana: an Early Problem in Australian Geology", Journal of Australian Studies, 39, 1993, 53-67.

[25] Stoddart, D. R., "Coral Islands, by Charles Darwin, with introduction, map and remarks", Washington, DC: Atoll Research Bulletin, No 88, Pacific Science Board, 1962.

[26] Armstrong, P. H., "Darwin's Desolate Islands: a Naturalist in the Falklands. 1833 and 1834", Chippenham: Picton Publishing, 1992. 